Full length article

\title{
Risk disclosure noncompliance
}

\author{
Axel F.A. Adam-Müller ${ }^{\mathrm{a}, \mathrm{b}}$, Michael H.R. Erkens ${ }^{\mathrm{c}, *}$ \\ ${ }^{\text {a } T r i e r ~ U n i v e r s i t y, ~ U n i v e r s i t a ̈ t s r i n g ~ 15, ~} 54296$ Trier, Germany \\ ${ }^{\mathrm{b}}$ Lancaster University Management School, Bailrigg, Lancaster LA1 4YX, United Kingdom \\ ${ }^{\mathrm{c}}$ Erasmus School of Economics, Burgemeester Oudlaan 50, 3062 PA Rotterdam, the Netherlands
}

\section{A R T I C L E I N F O}

\section{Article history:}

Available online 7 May 2020

\section{JEL classification:}

G18

G30

M41

M48

Keywords:

Risk disclosure

Enforcement

Noncompliance

\begin{abstract}
A B S T R A C T
We examine companies' compliance with IFRS risk disclosure rules for the first fiscal year following 2007. For a sample of 383 firms from 20 European countries, we find that average risk disclosure compliance is only 62 percent. Countries' enforcement strength is generally positively associated with risk disclosure compliance and even more effective in the presence of outsider monitoring. We highlight that cross-country differences in enforcement must be properly accounted for to ensure consistent risk disclosure compliance.
\end{abstract}

(c) 2020 Elsevier Inc. All rights reserved.

\section{Introduction}

Reporting practices differ widely across industries and countries. To facilitate the interpretation of accounting information, the comparability of financial statements is of paramount importance. The dominant approach to achieving this objective is to harmonize reporting standards. To date, many countries obligate companies to report in accordance with the International Financial Reporting Standards (IFRS). However, it cannot be taken for granted that harmonizing accounting standards is sufficient to make reporting comparable. Corporate reporting is affected not only by company-specific factors but also by country-specific factors such as a country's strength of enforcement of accounting regulations and by the need for information from the company's stakeholders.

Our study addresses two questions: Do companies comply with harmonized accounting standards such that their riskreporting behavior is consistent and comparable? Moreover, if companies do not comply, what is the likely cause of this noncompliance? We answer these questions by focusing on companies' risk disclosure based on an item-by-item disclosure analysis. Risk disclosure has specific rationales that have been underinvestigated in nonrisk-related research. For example, risk disclosure (i) conveys information that is hard to verify and highly subjective compared to other areas of disclosure, (ii) is a particularly sensitive area for reporting due to information spillovers to competitors and stakeholders (Adam et al., 2007), and (iii) is the outcome of disclosure choices that differ from other forward-looking disclosures, such as earnings guidance. While both guidance and risk disclosures refer to presently unobservable future amounts, guidance is often presented as a quantitative point estimate of future earnings (Anilowski et al., 2007). In contrast, risk disclosures focus implicitly or explicitly on the probability distribution, rather than on just the mean, of the outcome of interest.

Analyzing the 2007 annual reports of 383 European listed companies from 20 countries yields two main findings: First, companies hardly ever fully comply with disclosure requirements as set forth in the IFRS. On average, companies only report

\footnotetext{
* Corresponding author.

E-mail addresses: adam-mueller@uni-trier.de, a.adam-mueller@lancaster.ac.uk (A.F.A. Adam-Müller), erkens@ese.eur.nl (M.H.R. Erkens).
} 
62 percent of the items that they are obliged to report. Because all companies follow the same reporting standards, our finding is puzzling. Second, we document that enforcement strength is associated with disclosure compliance in an economically and statistically significant way and that enforcement strength interacts with company-level characteristics, suggesting that enforcement strength varies even for companies within the same country.

We contribute to the literature in three ways. First, we add to the literature on risk disclosure compliance by analyzing a large and unique dataset. Our dataset ensures that all companies apply the same accounting standards, as they are all headquartered in the European Economic Area. Our dataset also allows us to analyze the first-time effect of IFRS 7 on risk disclosure behavior. IFRS 7, in combination with IAS 32 and IAS 39, is perceived to be among the most difficult reporting standards in regard to interpretation and consistent application, resulting in considerable discretion in the standards' implementation. Given this discretion, enforcement strength is expected to play an even more pronounced role in companies' disclosure choices.

Second, we focus on a disclosure score as a direct measure of disclosure intensity rather than investigating the cause of heterogeneity in disclosure quality using indirect measures (e.g., conservatism, earnings response coefficients). The disclosure intensity approach involves a quantitative measure of disclosure and constitutes the foundation of disclosure index studies such as Botosan (1997) and Bushman et al. (2004). This approach allows for comparing disclosure compliance across companies and suggests that disclosure quantity is an intuitive aspect of disclosure compliance and transparent reporting (Columbano and Trombetta, 2019). We are thus able to emphasize the questions of what and whether companies report rather than how they report and how the market perceives the reporting.

Third, we tackle the question of whether harmonizing reporting standards is enough to ensure comparable reporting. We emphasize the importance of enforcement strength when analyzing companies' disclosure practices. We also contribute to a better understanding of how enforcement affects reporting outcomes by documenting a complementary effect of outsiders' need for risk information and country-level enforcement. Our study complements findings from Cascino and Gassen (2015), who document disclosure noncompliance for nonrisk-related disclosure by German and Italian firms. Contrary to our study, these authors do not investigate the role of institutions as determinants of compliance but rather as a moderator of the effect of compliance on post-IFRS comparability.

\section{Risk disclosure and hypothesis}

We focus on disclosure and are, to the best of our knowledge, the first to study the risk disclosure compliance of nonfinancial companies across a large set of countries.

In principle, risk disclosure might have several dimensions. It might reduce asymmetric information on the exposure to systematic risk factors or on idiosyncratic risks, but it might also disclose information on how a company deals with various types of risks by offering details on risk management systems and policies in general or positions in financial derivatives aimed at managing tradable risks. By its very nature, risk disclosure is largely forward looking, contrasting with most other accounting disclosures, which focus on past performance or events. Investors and other users of financial statements do not even have to be risk averse or ambiguity averse with respect to a company's cash flows or market values to benefit from risk disclosure; this fact provides strong theoretical backing for practitioners' demand for risk disclosure. ${ }^{1}$

Regulators have reacted to these information needs by requiring or recommending that firms disclose risk information, for example, by imposing the IFRS 7 regulation. However, risk and financial instrument disclosure standards are complex and complicated to implement (Lins et al., 2011). The complexity of the disclosure requirements is also acknowledged by standard-setters and regulators. As early as 1997, the SEC concluded that risk and financial instrument disclosure rules are often incomplete and, in some circumstances, misleading. As recently as 2014, the IASB stated in its introduction to IFRS 9 that the requirements for risk and financial instrument disclosure are difficult to understand, apply and interpret. One reason for this difficulty is that risk disclosures are highly subjective and hard to verify externally, resulting in considerable discretion on the part of the manager. ${ }^{2}$ Hence, what is intended by regulators to be mandatory risk disclosure can be expected to effectively contain significant elements of voluntary disclosure.

Before developing our hypothesis, we briefly review the theoretical and empirical literature on risk disclosure. Since Verrecchia (1983) and Dye (1985), an extensive literature on corporate disclosure theory has evolved. More recent contributions include Einhorn and Ziv (2008), Jorgensen and Kirschenheiter (2012, 2015), Cheynel (2013), Dye (2017) and Dye and Hughes (2018), among others. ${ }^{3}$ In the signaling games analyzed in these papers, a manager discloses information about the mean of firm value or cash flow. In contrast, the literature on risk disclosure analyzes the impact of revealing information on the variance or related measures of dispersion. This strand of the literature is significantly smaller: In Jorgensen and Kirschenheiter (2003, 2007), a manager may disclose perfect information on the variance, whereas Heinle and Smith (2017) focus on an imperfect signal about cash flow variance. Heinle et al. (2018) analyze the disclosure of systematic risk factors to investors, while Smith (2019) focuses on the disclosure of idiosyncratic risk in a Kyle (1985) type model. Lin (2019) considers qualitative risk disclosure to ambiguity-averse investors.

\footnotetext{
1 To be more specific, qualitative and quantitative risk disclosure is vital in enabling financial statement users to assess, for example, liquidity, market and credit risks.

${ }^{2}$ For example, Linsley and Shrives (2000) emphasize that disclosure regulation may not overrule managers' incentives to hide sensitive risk information that may reveal potential vulnerabilities for a company's going concern.

${ }^{3}$ Verrecchia (2001) and Dye (2001) provide excellent surveys of the disclosure theory literature.
} 
Per se, disclosing information to corporate outsiders reduces information asymmetry and might thus reduce agency costs. While earlier theoretical contributions indicate that this is likely to reduce the cost of capital ${ }^{4}$, Heinle et al. (2018) call this into question. In addition, disclosure, including risk disclosure, might trigger various types of direct or indirect costs, such as the costs of revealing proprietary information to competitors. Moreover, managers might incur proprietary costs themselves as a result of corporate information being disclosed to their monitors. Consequently, disclosure incentives on the part of managers are far from clear. As Abraham and Shrives (2014) point out, there is no comprehensive theory that clearly identifies the determinants of discretionary disclosure; we share their view with respect to the theory on risk disclosure.

Identifying 32 papers published over the last 20 years, Elshandidy et al. (2018) provide an excellent overview of the empirical literature on corporate risk disclosure. ${ }^{5}$ They demonstrate significant divergence with regard to mandatory versus voluntary disclosure, manual versus automated content analysis, within-country versus cross-country analysis, and risk disclosure of financial versus nonfinancial firms. Elshandidy et al. (2018) identify only one other paper that, like our paper, analyzes mandatory risk disclosure of nonfinancial companies ${ }^{6}$ in a cross-country setting. However, that paper, by Elshandidy et al. (2015), uses automated textual analysis, applied to data from three countries with dissimilar accounting standards, and finds that country characteristics such as the legal system and cultural values have high explanatory power over mandatory risk reporting variations over time, even under international convergence of accounting standards. In our paper, however, we manually collect data from annual reports from 20 countries with identical standards and explain the variation in risk disclosure compliance between firms across countries.

This paper focuses on an accounting standard that should lead to harmonization within Europe. Studies that analyze the effects of harmonizing accounting standards are discordant. Some studies show that harmonized standards result in fewer adverse selection problems, lower financing costs and reduced information asymmetries (e.g., Barth et al., 2008; Daske et al., 2008). Other studies conclude that heterogeneous institutions can result in lower-quality reporting even in the presence of harmonized standards (e.g., Holthausen, 2003; La Porta et al., 2008). Combining the two streams of literature, it is essentially an empirical question whether the adoption of the IFRS has led to consistent risk disclosure across countries.

This paper focuses on differences in enforcement strength across countries. Prior studies find that enforcement strength is positively related to the correct application and implementation of reporting standards (Ball, 2006) and expect a more pronounced role for enforcement if more and more companies apply the same reporting standards (Leuz, 2010). Consequently, differences in enforcement strength will amplify and result in more diverse outcomes. For example, Armstrong et al. (2010) document a negative market reaction to the adoption of the IFRS in countries with weak enforcement mechanisms; Li (2010) shows that IFRS adoption reduces financing costs only in countries with strong enforcement.

Despite ample evidence of the influence of enforcement on capital market outcomes, evidence of the effect of enforcement on risk disclosure compliance is still lacking. We expect enforcement strength to be positively related to disclosure compliance after controlling for differences in countries' institutional settings. We would expect no association if companies were to implement existing rules correctly and comply with all requirements.

We also expect that disclosure compliance varies across companies even within the same country because country-level enforcement is likely to interact with company-specific factors. We hypothesize that the need for accounting information by outsiders interacts with enforcement strength. More specifically, we presume that the association between enforcement and disclosure compliance is stronger when there is more scrutiny and a larger need for risk information from outsiders. There are two reasons for this: First, outsiders monitor the company, as they need risk information for contracting purposes. Their presence might have a positive first-order effect on risk disclosure compliance. Second, heightened scrutiny has a stronger effect in countries with strong enforcement mechanisms in place: Noncompliance is more likely to be detected under heightened scrutiny and should more likely result in legal action in countries with strong enforcement mechanisms. We therefore expect a second-order effect of outsider scrutiny on disclosure compliance. To explore this issue, we build on Jensen and Meckling (1976) and assume that risk information is crucial for monitoring. Consequently, risk disclosure is more important for companies that are monitored more closely by (a) lenders, (b) international investors, and (c) financial analysts.

In sum, we hypothesize the following:

Hypothesis. The association between enforcement strength and risk disclosure compliance is positive and stronger if company outsiders rely more heavily on risk information.

\section{Sample and variables}

Our sample is a random draw of 300 nonfinancial companies listed in the Dow Jones STOXX Europe 600 (as of May 31, 2009), comprising the 600 largest companies from 17 European countries. We require at least 10 companies per country and manually add companies (if they appear in the national stock index and if they have an annual report in English available) for countries otherwise represented by fewer than 10 companies. We also add at least 10 companies from the three largest European countries (by population) that are not represented in the STOXX index: Czech Republic, Hungary and Poland. Our final sample contains 383 companies from 20 countries. Details are provided in Table 1.

\footnotetext{
4 See Bertomeu and Cheynel (2016) for an overview.

5 See also Dobler (2008).

${ }^{6}$ Bischof et al. (2019) analyze risk disclosure by banks.
} 
Table 1

Sample.

\begin{tabular}{|c|c|c|c|c|}
\hline \multicolumn{5}{|c|}{ Panel A: Firms by country } \\
\hline & EURO STOXX 600 & Filled-up & Final sample & Percent \\
\hline Austria & 7 & 4 & 11 & $2.9 \%$ \\
\hline Belgium & 10 & 0 & 10 & $2.6 \%$ \\
\hline Czech Republic & 0 & 10 & 10 & $2.6 \%$ \\
\hline Denmark & 12 & 0 & 12 & $3.1 \%$ \\
\hline Finland & 13 & 0 & 13 & $3.4 \%$ \\
\hline France & 42 & 0 & 42 & $11.0 \%$ \\
\hline Germany & 55 & 0 & 55 & $14.4 \%$ \\
\hline Greece & 6 & 5 & 11 & $2.9 \%$ \\
\hline Hungary & 0 & 11 & 11 & $2.9 \%$ \\
\hline Ireland & 7 & 3 & 10 & $2.6 \%$ \\
\hline Italy & 13 & 0 & 13 & $3.4 \%$ \\
\hline Luxemburg & 4 & 6 & 10 & $2.6 \%$ \\
\hline Netherlands & 19 & 0 & 19 & $5.0 \%$ \\
\hline Norway & 8 & 3 & 11 & $2.9 \%$ \\
\hline Poland & 0 & 14 & 14 & $3.7 \%$ \\
\hline Portugal & 7 & 3 & 10 & $2.6 \%$ \\
\hline Spain & 21 & 0 & 21 & $5.5 \%$ \\
\hline Sweden & 15 & 0 & 15 & $3.9 \%$ \\
\hline Switzerland & 16 & 0 & 16 & $4.2 \%$ \\
\hline United Kingdom & 69 & 0 & 69 & $18.0 \%$ \\
\hline Total & 324 & 59 & 383 & $100.0 \%$ \\
\hline \multicolumn{5}{|c|}{ Panel B: Firms by industry } \\
\hline 1-digit SIC & \multicolumn{2}{|l|}{ Industry } & $\mathbf{N}$ & Percent \\
\hline 1 & \multicolumn{2}{|c|}{ mining and construction } & 43 & $11.2 \%$ \\
\hline 2,3 & \multicolumn{2}{|c|}{ manufacturing } & 190 & $49.6 \%$ \\
\hline 4 & \multicolumn{2}{|c|}{ transportation } & 77 & $20.0 \%$ \\
\hline 5 & \multicolumn{2}{|c|}{ trade } & 35 & $9.1 \%$ \\
\hline 7 & \multicolumn{2}{|c|}{ services } & 27 & $7.0 \%$ \\
\hline 8 & \multicolumn{2}{|c|}{ public administration } & 11 & $2.9 \%$ \\
\hline Total & & & 383 & $100.0 \%$ \\
\hline
\end{tabular}

Table 1 shows our sample composition by country (Panel A) and by industry (Panel B). We first randomly chose 300 non-financial companies from the Dow Jones Euro STOXX 600. We then manually added more companies to the sample so that we have at least 10 companies per country. The added companies are taken from, if available, the Euro STOXX 600 or, if not available, from the leading stock market in each country. We also added companies from the leading national stock market of the Czech Republic, Hungary, and Poland.

More than 40 percent of companies are headquartered in France, Germany, or the UK. As IFRS 7 became effective in 2007, the analyses are based on data from the first fiscal year starting after that date. ${ }^{7}$ We collect risk data from annual reports. Other data sources are Compustat, Datastream, I/B/E/S, Reuters, and Ding et al. (2005) and Kaufmann et al. (2009).

We develop a compliance score that is based on mandatory disclosure requirements as outlined in IFRS 7 and IAS 39. The maximum number of items is 26 (see Table 2). If an item is disclosed, we assign the indicator variable a value of 1 and 0 otherwise. We sum up all indicators and divide the actual disclosure level by the possible disclosure level to obtain the compliance score. We do not penalize the nondisclosure of irrelevant disclosure items. For example, if a company is not exposed to commodity risks, we do not include any item that relates to commodity risks.

Panels A and B of Table 3 present descriptive statistics for the compliance score and all other variables. The average compliance is surprisingly low at 62 percent, with a minimum of 10 percent and a maximum of 92 percent. The highest average compliance is observed among companies domiciled in Finland (72 percent) and Austria and Germany (68 percent each). It is lowest among companies from Hungary (46 percent), Greece (51 percent), and the Czech Republic (52 percent).

The low disclosure compliance may be due to the following reasons. First, our analyses not only focus on Western European countries with relatively homogenous capital markets and institutions but also include countries with different characteristics. These differences may partially account for our findings. Second, theory predicts that companies may withhold sensitive risk information. Dobler et al. (2011) suggest that noncompliance with risk disclosure rules is aimed at circumventing political scrutiny. Third, risk disclosure can be subjective and difficult to verify for outsiders; thus, executives might withhold information that is not easily verifiable.

Our main independent variable is enforcement. It is the first and only factor (with an eigenvalue larger than 1) that emerges from a factor analysis using four components: corruption, legislative effectiveness, rule-of-law, and regulatory quality, all taken from Kaufmann et al. (2009). Other country-level variables are business liberty (movement of capital); a country's market capitalization, scaled by GDP (economic strength); absence and divergence of accounting standards (differences

\footnotetext{
${ }^{7}$ A disadvantage is that we only have one year of data, such that all inferences are drawn from purely cross-sectional correlations, not lending themselves to causal interpretation.
} 
Table 2

Disclosure compliance check-list.

\begin{tabular}{|c|c|c|c|}
\hline & $\begin{array}{l}\text { \# of companies that should } \\
\text { disclose }\end{array}$ & $\begin{array}{l}\text { \# of companies that do } \\
\text { disclose }\end{array}$ & $\begin{array}{l}\text { Compliance } \\
\text { (percent) }\end{array}$ \\
\hline Commodity risk: exposure & 137 & 8 & $5.84 \%$ \\
\hline Commodity risk: sensitivity analysis description & 137 & 81 & $59.12 \%$ \\
\hline Commodity risk: sensitivity analysis first detail & 137 & 76 & $55.47 \%$ \\
\hline Commodity risk: sensitivity analysis second detail & 137 & 46 & $33.58 \%$ \\
\hline Concentration of risks & 383 & 78 & $20.37 \%$ \\
\hline Credit risk: exposure & 383 & 132 & $34.46 \%$ \\
\hline Derivatives: book value per hedge accounting type & 300 & 236 & $78.67 \%$ \\
\hline Derivatives: impact on profit and loss & 346 & 308 & $89.02 \%$ \\
\hline Fair value: financial assets & 383 & 342 & $89.30 \%$ \\
\hline Fair value: financial liabilities & 383 & 231 & $60.31 \%$ \\
\hline Fair value: note on computation & 356 & 217 & $60.96 \%$ \\
\hline Financial instruments: impact on equity & 383 & 171 & $44.65 \%$ \\
\hline Financial instruments: impact on P\&L & 383 & 184 & $48.04 \%$ \\
\hline Financial instruments: book value per category & 383 & 244 & $63.71 \%$ \\
\hline Financial liabilities: maturity analysis & 383 & 373 & $97.39 \%$ \\
\hline Foreign exchange risk: exposure & 367 & 133 & $36.24 \%$ \\
\hline $\begin{array}{l}\text { Foreign exchange risk: sensitivity analysis } \\
\text { description }\end{array}$ & 367 & 315 & $85.83 \%$ \\
\hline Foreign exchange risk: sensitivity analysis first detail & 367 & 306 & $83.38 \%$ \\
\hline $\begin{array}{l}\text { Foreign exchange risk: sensitivity analysis second } \\
\text { detail }\end{array}$ & 367 & 199 & $54.22 \%$ \\
\hline Interest rate risk: exposure & 361 & 80 & $22.16 \%$ \\
\hline Interest rate risk: sensitivity analysis description & 361 & 322 & $89.20 \%$ \\
\hline Interest rate risk: sensitivity analysis first detail & 361 & 314 & $86.98 \%$ \\
\hline Interest rate risk: sensitivity analysis second detail & 361 & 149 & $41.27 \%$ \\
\hline Liquidity risk: exposure & 383 & 237 & $61.88 \%$ \\
\hline Operational risk management strategy & 383 & 181 & $47.26 \%$ \\
\hline Financial risk management strategy & 383 & 357 & $93.21 \%$ \\
\hline Average disclosure compliance score & & & $61.96 \%$ \\
\hline
\end{tabular}

Table 2 outlines the disclosure check-list to build our disclosure compliance score.

between local GAAP and the IFRS); economic volatility (variability in economic strength); and indicators for common and German law (differences in legal origins).

To control for companies' business characteristics and executives' incentives, we employ the following firm-level variables: analysts following, BIG4 auditor, cash flow variability, debt increase, equity increase, future abnormal returns, growth opportunities, industry membership, institutional ownership, internationality, leverage, profitability, size, and trading on own account. All variables are defined in the Appendix.

\section{Empirical results}

To test our hypothesis on the association between disclosure compliance, enforcement, and outsider scrutiny, we estimate the following OLS model:

disclosure compliance $_{\mathrm{i}}=\alpha+\beta_{1}$ enforcement $_{\mathrm{c}}+\beta_{2}$ outsider's scrutiny $_{\mathrm{i}}+\beta_{3}$ enforcement $_{\mathrm{c}} \mathrm{x}$

$$
\text { outsider scrutiny } \mathrm{i}_{\mathrm{i}}+\gamma_{1} \text { country }- \text { level controls } \mathrm{c}+\gamma_{2} \text { firm }- \text { level controls } \mathrm{s}_{\mathrm{i}}+\varepsilon_{\mathrm{i}}
$$

whereby the subscript $i$ denotes observations at the firm level and the subscript $c$ denotes observations at the country level. All continuous variables are standardized to ease interpretation and comparison across regressions. Standard errors are bootstrapped with 500 replications, while each replication is a bootstrap sample of country clusters. ${ }^{8}$ We inspect the variance inflation factors (VIFs) to assess multicollinearity; all are below 3.3.

We present our main results in Table 4. Column (1) presents the baseline model for the association between compliance and enforcement, while columns (2) to (5) present the results of analyzing the interaction between enforcement and outsider scrutiny and the associations of these two variables with compliance.

Enforcement is, as expected, positively related to disclosure compliance; its coefficient is significant at the 1-percent level, and an increase of one standard deviation in enforcement strength correlates to a 0.37-standard-deviation increase in disclosure compliance (a 6-percentage-point increase). The association is robust to including a large set of variables controlling for institutional and macro-level factors, as well as for companies' operations.

\footnotetext{
${ }^{8}$ In two untabulated tests, we (i) cluster standard errors at the country level and (ii) bootstrap standard errors while drawing replications from the entire sample of observations, instead of from country clusters. Our main findings remain qualitatively unchanged.
} 
Table 3

Descriptive statistics.

\begin{tabular}{|c|c|c|c|c|c|c|c|c|}
\hline \multicolumn{9}{|c|}{ Panel A: Descriptive statistics } \\
\hline & & $\mathbf{N}$ & mean & sd & $\min$ & \multicolumn{2}{|l|}{ p50 } & $\max$ \\
\hline \multicolumn{2}{|c|}{ Disclosure compliance } & 383 & 0.6196 & 0.1506 & 0.1000 & \multicolumn{2}{|l|}{0.6364} & 0.9259 \\
\hline \multicolumn{2}{|c|}{ Absence acc. standards } & 383 & 19.9060 & 14.2526 & 0.0000 & \multicolumn{2}{|l|}{21.0000} & 54.0000 \\
\hline \multicolumn{2}{|c|}{ Analyst following } & 383 & 15.3211 & 8.3462 & 0.0000 & \multicolumn{2}{|l|}{15.0000} & 40.0000 \\
\hline \multicolumn{2}{|c|}{ Attention } & 383 & 1.5196 & 0.9289 & 0.0000 & \multicolumn{2}{|l|}{2.0000} & 3.0000 \\
\hline \multicolumn{2}{|c|}{ BIG4 } & 383 & 0.9138 & 0.2810 & 0.0000 & \multicolumn{2}{|l|}{1.0000} & 1.0000 \\
\hline \multicolumn{2}{|c|}{ Business liberty } & 383 & 0.7774 & 0.1092 & 0.5177 & \multicolumn{2}{|l|}{0.7630} & 0.9070 \\
\hline \multicolumn{2}{|c|}{ Cash flow variability } & 383 & 4.5940 & 2.8819 & 0.0000 & \multicolumn{2}{|l|}{4.9807} & 12.3558 \\
\hline \multicolumn{2}{|c|}{ Debt increase } & 383 & 0.5065 & 0.5006 & 0.0000 & \multicolumn{2}{|l|}{1.0000} & 1.0000 \\
\hline \multicolumn{2}{|c|}{ Divergence acc. standards } & 383 & 30.6580 & 6.2951 & 17.0000 & \multicolumn{2}{|l|}{34.0000} & 38.0000 \\
\hline \multicolumn{2}{|c|}{ Economic volatility } & 383 & 1.7249 & 1.0811 & 0.7234 & 1.2597 & & 5.7390 \\
\hline \multicolumn{2}{|c|}{ Enforcement } & 383 & 0.1362 & 0.8436 & -1.8144 & 0.4153 & & 1.1763 \\
\hline Equity increas & & 383 & 0.5013 & 0.5007 & 0.0000 & 1.0000 & & 1.0000 \\
\hline Future abnorn & return & 383 & -0.0237 & 0.3346 & -0.4970 & -0.0837 & & 1.8067 \\
\hline Growth oppor & nities & 383 & 0.0397 & 0.0553 & -0.0186 & 0.0289 & & 0.4763 \\
\hline Institutional o & hership & 383 & 0.3233 & 0.2698 & 0.0000 & 0.2837 & & 0.9706 \\
\hline Internationali & & 383 & 0.3285 & 0.2972 & 0.0000 & 0.3102 & & 0.9377 \\
\hline Leverage & & 383 & 0.2530 & 0.1645 & 0.0004 & 0.2321 & & 0.8204 \\
\hline Market capita & ation (country) & 383 & 1.6989 & 1.2602 & 0.0045 & 1.3180 & & 4.0955 \\
\hline Profitability & & 383 & 0.0920 & 0.0810 & -0.2320 & 0.0785 & & 0.3465 \\
\hline Size & & 383 & 8.7665 & 1.6624 & 4.4226 & 8.7411 & & 12.3719 \\
\hline Trading on ov & account & 383 & 0.0627 & 0.2427 & 0.0000 & 0.0000 & & 1.0000 \\
\hline Panel B: Des & ptive statistics & country & & & & & & \\
\hline Country & $\begin{array}{l}\text { Absence acc. } \\
\text { std. }\end{array}$ & $\begin{array}{l}\text { Business } \\
\text { liberty }\end{array}$ & $\begin{array}{l}\text { Disclosure } \\
\text { compliance }\end{array}$ & $\begin{array}{l}\text { Divergence acc. } \\
\text { std. }\end{array}$ & $\begin{array}{l}\text { Economic } \\
\text { volatility }\end{array}$ & Enforcement & $\begin{array}{l}\text { Market } \\
\text { capitalizat }\end{array}$ & tion \\
\hline Austria & 34 & 0.7390 & 0.6839 & 36 & 2.6168 & 0.6348 & 0.3276 & \\
\hline Belgium & 22 & 0.8753 & 0.6292 & 32 & 1.3036 & 0.1392 & 0.5578 & \\
\hline $\begin{array}{l}\text { Czech } \\
\text { Republic }\end{array}$ & 44 & 0.7037 & 0.5195 & 20 & 3.5782 & -1.1469 & 0.2407 & \\
\hline Denmark & 31 & 0.8827 & 0.5621 & 21 & 0.7881 & 1.1763 & 0.7794 & \\
\hline Finland & 22 & 0.8177 & 0.7165 & 31 & 2.8698 & 0.9176 & 2.2112 & \\
\hline France & 21 & 0.6573 & 0.6441 & 34 & 0.7234 & -0.3200 & 1.3180 & \\
\hline Germany & 18 & 0.7630 & 0.6805 & 38 & 2.0100 & 0.4153 & 1.0119 & \\
\hline Greece & 40 & 0.5323 & 0.5086 & 28 & 2.8561 & -1.4869 & 0.489 & \\
\hline Hungary & 40 & 0.6673 & 0.4619 & 26 & 0.9668 & -1.1031 & 0.3423 & \\
\hline Ireland & 0 & 0.9070 & 0.6710 & 34 & 2.4548 & 0.6066 & 0.5261 & \\
\hline Italy & 27 & 0.6900 & 0.5836 & 37 & 1.0604 & -1.6072 & 1.0932 & \\
\hline Luxemburg & 54 & 0.8230 & 0.6103 & 17 & 2.3832 & 0.8739 & 0.0045 & \\
\hline Netherlands & 10 & 0.8613 & 0.6394 & 25 & 2.4998 & 0.7865 & 2.3171 & \\
\hline Norway & 7 & 0.6370 & 0.6404 & 17 & 1.1484 & 0.7481 & 1.2177 & \\
\hline Poland & 23 & 0.5177 & 0.5840 & 30 & 5.7390 & -1.8144 & 0.1988 & \\
\hline Portugal & 29 & 0.6620 & 0.5658 & 22 & 1.1814 & -0.7821 & 0.6474 & \\
\hline Spain & 28 & 0.7600 & 0.5463 & 29 & 0.9045 & -0.5835 & 2.0558 & \\
\hline Sweden & 10 & 0.8140 & 0.5427 & 26 & 1.2597 & 0.9009 & 2.0947 & \\
\hline Switzerland & 42 & 0.7470 & 0.6271 & 22 & 1.7454 & 0.9499 & 4.0955 & \\
\hline $\begin{array}{l}\text { United } \\
\quad \text { Kingdom }\end{array}$ & 0 & 0.9040 & 0.6377 & 35 & 1.0584 & 0.6952 & 3.6886 & \\
\hline
\end{tabular}

Table 3, Panel A shows descriptive statistics for our dependent and independent variables. Variables are defined in the Appendix.

Table 3, Panel B shows descriptive statistics for the dependent and independent variables by country. Variables are defined in the Appendix.

We also find that future debt issuances, divergence of accounting standards, economic volatility, leverage, size, and trading on own account are positively associated with compliance, whereas future equity issuances and abnormal returns are negatively associated with compliance. Thus, firms comply more if they are more closely monitored due to their mere size and/or due to their reliance on debt financing. Companies are also more compliant if differences between local GAAP and the IFRS are larger, suggesting that divergence in standards makes companies more sensitive to applying new rules correctly. Furthermore, the association of a more volatile economic environment with higher compliance suggests that risk disclosure is needed more under such circumstances. Firms issuing equity within the next two years are associated with less risk disclosure compliance, possibly because they are trying to obtain more favorable financing conditions by hiding risk exposure.

Next, we test whether outsider scrutiny moderates the relation between disclosure compliance and enforcement strength. We proxy for outsider scrutiny via three indicator variables, all taking the value of 1 if the respective continuous variable is larger than the sample median and 0 otherwise. The three variables are the number of analysts following a company, the ratio of foreign assets to total assets, and the leverage ratio. Each indicator variable interacts with enforcement strength. We also create the variable attention as the sum of all indicator variables. 
Table 4

Disclosure compliance and enforcement.

\begin{tabular}{|c|c|c|c|c|c|}
\hline & \multirow[t]{3}{*}{$(1)$} & (2) & $(3)$ & $(4)$ & $(5)$ \\
\hline & & \multicolumn{3}{|c|}{ Conditional variable $(0 / 1)$} & \multirow{2}{*}{$\begin{array}{l}\text { Sum of (2-4) } \\
\text { Attention }\end{array}$} \\
\hline & & Analyst follow. & Internationality & Leverage & \\
\hline \multirow[t]{2}{*}{ Enforcement } & $0.3689^{* * *}$ & $0.3026^{* * *}$ & $0.3390^{* * *}$ & $0.2912^{* *}$ & $0.2184^{*}$ \\
\hline & $(2.99)$ & $(2.70)$ & $(2.62)$ & $(2.51)$ & $(1.70)$ \\
\hline \multirow[t]{2}{*}{ Conditional variable } & & 0.0036 & 0.2422 & $0.2156^{* *}$ & $0.1723^{* *}$ \\
\hline & & $(0.04)$ & $(1.40)$ & $(2.39)$ & $(2.17)$ \\
\hline \multirow[t]{2}{*}{ Enforcement $\times$ cond. variable } & & $0.2256^{* *}$ & 0.0949 & $0.1478^{* *}$ & $0.1373^{* *}$ \\
\hline & & $(2.10)$ & $(0.44)$ & $(1.99)$ & $(2.32)$ \\
\hline \multirow[t]{2}{*}{ Absence acc. standards } & 0.1175 & 0.1393 & 0.1294 & 0.1261 & 0.1569 \\
\hline & $(0.56)$ & $(0.70)$ & $(0.60)$ & $(0.65)$ & $(0.84)$ \\
\hline \multirow[t]{2}{*}{ Analyst following } & 0.0450 & & 0.0461 & 0.0450 & \\
\hline & $(0.67)$ & & $(0.71)$ & $(0.69)$ & \\
\hline \multirow[t]{2}{*}{ BIG4 } & 0.2892 & 0.3127 & 0.2880 & 0.2919 & 0.3323 \\
\hline & $(1.09)$ & $(1.16)$ & $(1.09)$ & $(1.14)$ & $(1.30)$ \\
\hline \multirow[t]{2}{*}{ Business liberty } & -0.2111 & -0.2279 & -0.2093 & -0.2119 & -0.2301 \\
\hline & $(-1.18)$ & $(-1.29)$ & $(-1.11)$ & $(-1.25)$ & $(-1.21)$ \\
\hline \multirow[t]{2}{*}{ Cash flow variability } & -0.0217 & -0.0129 & -0.0193 & -0.0241 & -0.0284 \\
\hline & $(-0.46)$ & $(-0.29)$ & $(-0.40)$ & $(-0.51)$ & $(-0.60)$ \\
\hline \multirow[t]{2}{*}{ Common law } & 0.3404 & 0.3077 & 0.3401 & 0.3165 & 0.3591 \\
\hline & $(0.68)$ & $(0.71)$ & $(0.65)$ & $(0.65)$ & $(0.83)$ \\
\hline \multirow[t]{2}{*}{ Debt increase } & $0.2713^{* *}$ & $0.2655^{* *}$ & $0.2522^{* *}$ & $0.2803^{* * *}$ & $0.2439^{* *}$ \\
\hline & $(2.41)$ & $(2.28)$ & $(2.29)$ & $(2.59)$ & $(2.34)$ \\
\hline \multirow[t]{2}{*}{ Divergence acc. standards } & $0.2298^{* *}$ & $0.2568^{* *}$ & $0.2338^{* *}$ & $0.2239^{* *}$ & $0.2375^{* *}$ \\
\hline & $(2.33)$ & $(2.39)$ & $(2.26)$ & $(2.44)$ & $(2.50)$ \\
\hline \multirow[t]{2}{*}{ Economic volatility } & $0.1863^{*}$ & $0.1547^{*}$ & 0.1737 & $0.1795^{* *}$ & 0.1408 \\
\hline & $(1.93)$ & $(1.72)$ & $(1.60)$ & $(2.02)$ & $(1.50)$ \\
\hline \multirow[t]{2}{*}{ Equity increase } & $-0.1586^{*}$ & -0.1497 & $-0.1457^{*}$ & $-0.1528^{*}$ & -0.1116 \\
\hline & $(-1.80)$ & $(-1.63)$ & $(-1.74)$ & $(-1.77)$ & $(-1.26)$ \\
\hline \multirow[t]{2}{*}{ Future abnormal return } & $-0.1156^{* *}$ & $-0.1201^{* *}$ & $-0.1121^{* *}$ & $-0.1331^{* *}$ & $-0.1435^{* * *}$ \\
\hline & $(-2.17)$ & $(-2.28)$ & $(-2.08)$ & $(-2.52)$ & $(-2.87)$ \\
\hline \multirow[t]{2}{*}{ German law } & -0.1715 & -0.2175 & -0.1772 & -0.1814 & -0.2165 \\
\hline & $(-0.69)$ & $(-0.94)$ & $(-0.68)$ & $(-0.80)$ & $(-0.99)$ \\
\hline \multirow[t]{2}{*}{ Growth opportunities } & -0.0601 & -0.0596 & -0.0709 & -0.0572 & -0.0746 \\
\hline & $(-1.14)$ & $(-1.06)$ & $(-1.28)$ & $(-1.53)$ & $(-1.40)$ \\
\hline Institutional ownership & -0.0334 & -0.0213 & -0.0375 & -0.0230 & -0.0263 \\
\hline & $(-0.48)$ & $(-0.32)$ & $(-0.53)$ & $(-0.34)$ & $(-0.41)$ \\
\hline Internationality & 0.0931 & 0.0962 & & 0.0846 & \\
\hline & $(1.31)$ & $(1.35)$ & & $(1.30)$ & \\
\hline Leverage & $0.1067^{* *}$ & $0.1150^{* *}$ & $0.1054^{* *}$ & & \\
\hline & $(2.16)$ & $(2.41)$ & $(2.08)$ & & \\
\hline Market capitaliz. (country) & -0.0038 & -0.0077 & -0.0102 & 0.0091 & -0.0051 \\
\hline & $(-0.02)$ & $(-0.03)$ & $(-0.04)$ & $(0.04)$ & $(-0.03)$ \\
\hline Profitability & -0.0024 & -0.0019 & 0.0037 & -0.0073 & 0.0003 \\
\hline & $(-0.05)$ & $(-0.05)$ & $(0.08)$ & $(-0.17)$ & $(0.01)$ \\
\hline Size & $0.1445^{* *}$ & $0.1630^{* * * *}$ & $0.1391^{*}$ & $0.1570^{* *}$ & $0.1429^{* *}$ \\
\hline & $(2.15)$ & $(2.76)$ & $(1.95)$ & $(2.46)$ & $(1.97)$ \\
\hline Trading on own account & $0.3351^{*}$ & $0.3339^{*}$ & $0.3452^{*}$ & $0.3481^{*}$ & $0.3605^{* *}$ \\
\hline & $(1.82)$ & $(1.84)$ & $(1.90)$ & $(1.90)$ & $(2.09)$ \\
\hline Constant & -0.4769 & -0.4062 & -0.5410 & -0.5943 & -0.6548 \\
\hline & $(-1.07)$ & $(-0.95)$ & $(-1.16)$ & $(-1.39)$ & $(-1.40)$ \\
\hline Industry fixed effects & Yes & Yes & Yes & Yes & Yes \\
\hline $\mathrm{N}$ & 383 & 383 & 383 & 383 & 383 \\
\hline Adjusted $\mathrm{R}^{2}$ & 0.253 & 0.260 & 0.260 & 0.257 & 0.269 \\
\hline Wald $\mathrm{Chi}^{2}$ & 350.4 & 436.9 & 322.3 & 440.8 & 380.1 \\
\hline
\end{tabular}

Table 4 shows the results of OLS regressions of disclosure compliance on the set of firm- and country-level determinants. Column (1) presents the baseline model. The conditional variable in columns (2-4) is equal to 1 if the company has above sample median analyst following (column 2), foreign assets (column 3), or leverage (column 4), and 0 otherwise. The conditional variable in column (5), attention, is the sum of the conditional variables of columns (2-4). Each model contains industry fixed effects and all continuous variables are standardized. T-values are presented in parentheses and are based on bootstrapped standard errors (500 replications) while each replication is a bootstrap sample of country clusters. Variables are defined in the Appendix.

Consider the results in columns (2) to (4). The main effect of enforcement remains positive and significant. The coefficients on the indicator variables are larger in magnitude compared to the baseline model (with the exception of analyst following), but their respective statistical significance remains unchanged. The interaction terms of enforcement with high analyst following and high leverage load positive. In terms of economic magnitude, for companies with above-samplemedian analyst following (leverage), the association between enforcement strength and risk disclosure compliance is approximately 70 percent (50 percent) stronger than that of companies with below-median analyst following (leverage). 


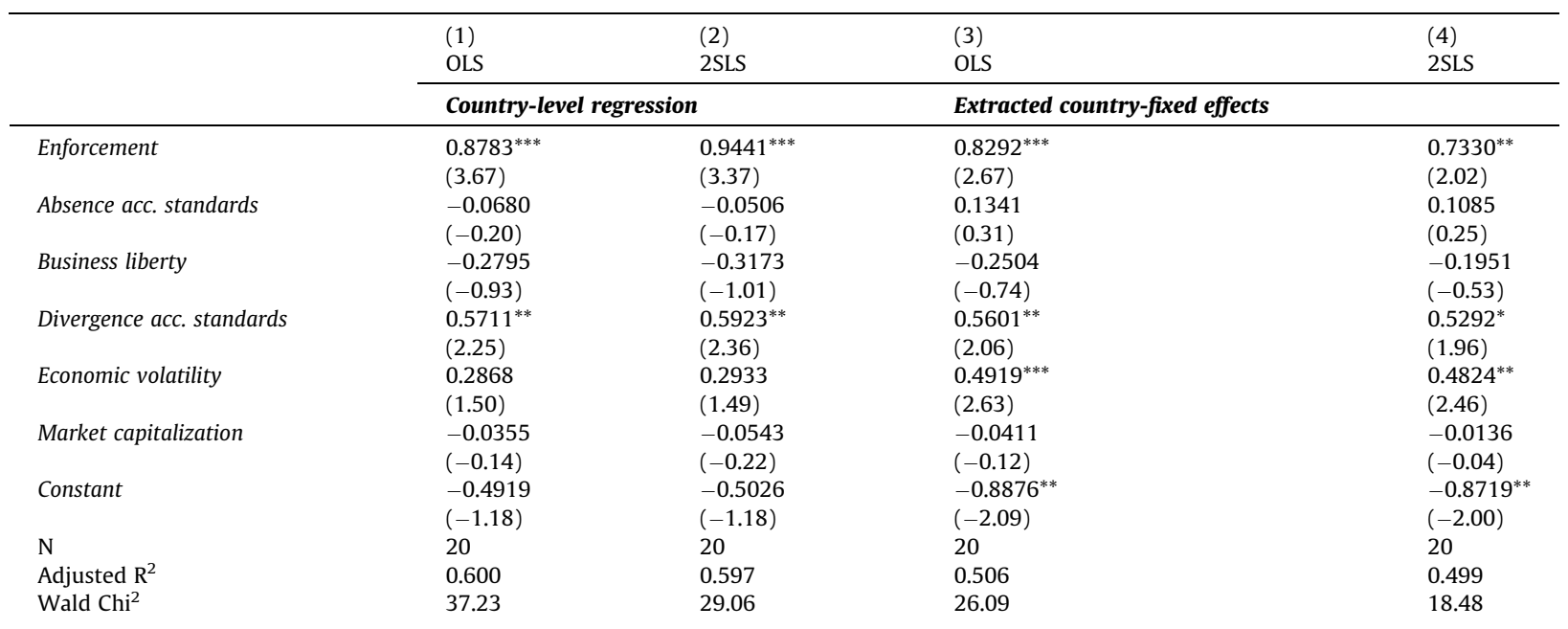

Table 5 shows the results of OLS regressions in columns (1) and (3), and two-stage least-squares regression in columns (2) and (4). For the two-stage leastsquares regression we use the countries legal origins (La Porta et al., 1998) and their real per capita GDP averaged from 1997 to 2006 as instrumental variables for enforcement. The dependent variable in models (1) and (2) is the country-average of firms' disclosure compliance. The dependent variable in models (3) and (4) is the extracted country-fixed effect from firm-level regressions of firms' disclosure compliance on the full set of firm characteristics. All continuous variables are standardized. T-values are presented in parentheses and are based on bootstrapped standard errors (500 replications). Variables are defined in the Appendix.

There is, however, no incremental effect for companies with high foreign exposure, suggesting that enforcement strength is insensitive to the level of foreign operations.

Column (5) presents the results for the variable attention. Our prior findings are corroborated: more scrutiny by outsiders due to a higher demand for accounting information strengthens the association between enforcement strength and disclosure compliance.

A limitation of our approach is that we have repeated observations per country for all country-level variables. We therefore also analyze our data at the country level to have just one observation per country by regressing the mean of the compliance score on all country characteristics. We estimate the following regression model:

$$
\text { disclosure compliance }_{\mathrm{c}}=\alpha+\beta_{1} \text { enforcement }_{\mathrm{c}}+\gamma_{1} \text { country - level controls } \mathrm{s}_{\mathrm{c}}+\varepsilon_{\mathrm{c}}
$$

Standard errors are bootstrapped with 500 replications. The findings are reported in column (1) of Table 5 and support our previous results. Enforcement and divergence load positive; all other variables are insignificant.

Our regressions assume that enforcement is exogenous. If, however, enforcement and disclosure levels are simultaneously determined, our results suffer from an endogeneity bias. We address this concern by running a two-stage leastsquares regression employing two instruments for enforcement: legal origin and per capita GDP averaged over ten years prior to 2007. While related to the level of enforcement, a country's legal origin can be considered predetermined and exogenous to our disclosure index (Levine, 1999). Moreover, an effective legal infrastructure is costly to create and maintain, and thus a country's wealth potentially influences the level of legal enforcement (Leuz et al., 2003). We present the second-stage results in column (2) of Table 5 ; they corroborate our main findings.

Finally, we control for variation in within-country heterogeneity based on an approach suggested by Hail and Leuz (2006). We first estimate (EQ1) and regress disclosure intensity on all firm-level variables but exclude all country-level variables. In lieu thereof, we include country indicator variables. We then extract the country fixed effects from this firm-level regression and regress them on all country-level variables in a country-level regression (similar to (EQ2) but with the country fixed effects as the dependent variable). This approach exploits firm-level information, controls for differences in withincountry economic heterogeneity, and allows us to analyze how much variation in the country fixed effects is explained by the institutional variables (Hail and Leuz, 2006). The results are presented in columns (3) and (4) of Table 5, again corroborating our previous findings.

\section{Conclusion}

We document remarkable variation in risk disclosure compliance for 383 European companies, which have an average compliance rate of only 62 percent. Our findings emphasize the role of enforcement in disclosure compliance and suggest that a mandate is truly "mandatory" only in the presence of courts and regulators that are willing to hold managers to account. We also emphasize that enforcement is more effective in the presence of outsider monitoring. Our findings imply that (i) researchers should control for enforcement strength in cross-country studies; (ii) simply harmonizing accounting 
regulations across countries does not guarantee risk disclosure compliance or suffice to ensure consistent disclosure across countries; and (iii) a tailored monitoring approach might be in order to ensure that the influence of differences in enforcement on risk disclosure compliance is reduced.

\section{Acknowledgements}

This study received financial support from the European Union's Marie Curie framework (INTACCT program, Contract No. MRTN-CT-2006-035850), and from the Deutsche Forschungsgemeinschaft (DFG, GZ AD 176/3-1). We appreciate the helpful comments of Hans Christensen, Ying Gan, Joachim Gassen, Martin Glaum, Gilles Hilary, Thomas Jeanjean, Tiphaine Jerôme, David Kreppel, Christian Leuz, Eddie Riedl, Hervé Stolowy, Stephen Young and workshop participants at the Campus for Finance 2013 Research Conference, DGF 2014 Annual Meeting, EAA 2014 Annual Meetings, EFMA 2015 conference, MFA 2013 Annual Meeting, and seminar participants at ERASMUS University Rotterdam, ESSCA Paris, HEC Paris, University of Konstanz and Trier University. All data is available from public sources.

\section{Appendix A. Variable definitions}

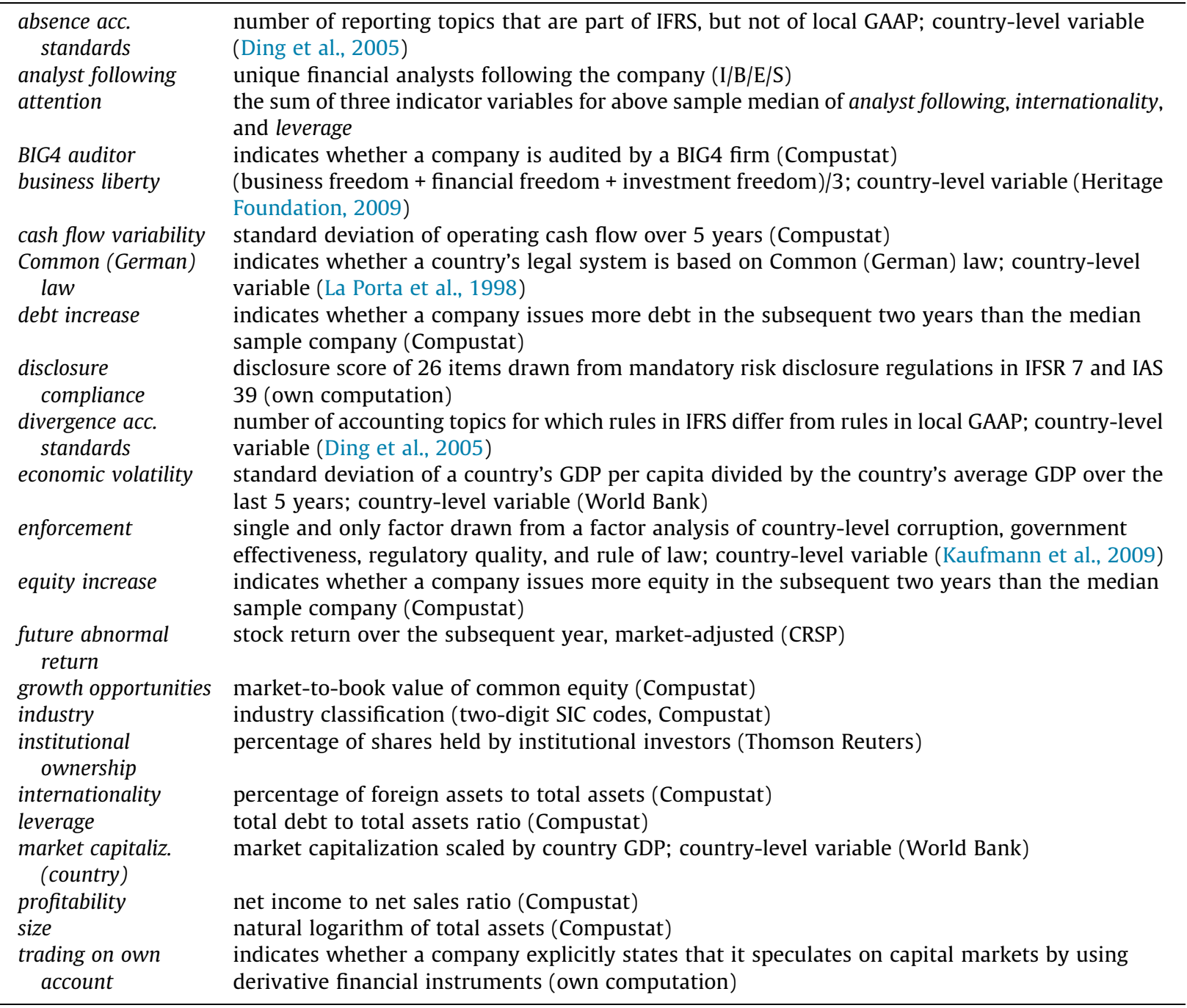

\section{Appendix B. Supplementary material}

Supplementary data to this article can be found online at https://doi.org/10.1016/j.jaccpubpol.2020.106739. 


\section{References}

Abraham, S., Shrives, P.J., 2014. Improving the relevance of risk factor disclosure in corporate annual reports. Br. Account. Rev. 46, 91-107.

Anilowski, C., Feng, M., Skinner, D.J., 2007. Does earnings guidance affect market returns? The nature and information content of aggregate earnings guidance. J. Account. Econ. 44, 36-63.

Adam, T., Dasgupta, S., Titman, S., 2007. Financial constraints, competition, and hedging in industry equilibrium. J. Finance 62, $2445-2473$.

Armstrong, C.S., Barth, M.E., Jagolinzer, A.D., Riedl, E.J., 2010. Market reaction to the adoption of IFRS in Europe. Account. Rev. 85, $31-61$.

Ball, R., 2006. International Financial Reporting Standards (IFRS): Pros and cons for investors. Account. Business Res. $36,5-27$.

Barth, M.E., Landsman, W.R., Lang, M.H., 2008. International accounting standards and accounting quality. J. Account. Res. 46, 467-498.

Bertomeu, J., Cheynel, E., 2016. Disclosure and the cost of capital. A survey of the theoretical literature. Abacus 52, $221-258$.

Bischof, J., Daske, H., Elfers, F., Hail, L., 2019. A tale of two regulators: Risk disclosures, liquidity, and enforcement in the banking sector. Working paper.

Botosan, C.A., 1997. Disclosure level and the cost of equity capital. Account. Rev. 72 (3), 323-349.

Bushman, R.M., Piotroski, J.D., Smith, A.J., 2004. What determines corporate transparency?. J. Account. Res. 42, $207-252$.

Cascino, S., Gassen, J., 2015. What drives the comparability effect of mandatory IFRS adoption?. Rev. Acc. Stud. 20, 242-282.

Cheynel, E., 2013. A theory of voluntary disclosure and cost of capital. Rev. Acc. Stud. 18, 987-1020.

Columbano, C., Trombetta, M., 2019. When do governments disclose, and when do they "go dark"? Evidence on governments' guidance transparency in presence of a mandatory guidance regime. Working paper.

Daske, H., Hail, L., Leuz, C., Verdi, R.S., 2008. Mandatory IFRS reporting around the world: Early evidence on the economic consequences. J. Account. Res. 46, 1085-1142.

Ding, Y., Jeanjean, T., Stolowy, H., 2005. Why do national GAAP differ from IAS? The role of culture. Int. J. Account. 40, 325-350.

Dobler, M., 2008. Incentives for risk reporting - A discretionary disclosure and cheap talk approach. Int. J. Account. 43, $184-2006$.

Dobler, M., Lajili, K., Zéghal, D., 2011. Attributes of corporate risk disclosure: An international investigation in the manufacturing sector. J. Int. Account. Res. $10,1-22$.

Dye, R.A., 1985. Disclosure of nonproprietary information. J. Account. Res. 23, 123-145.

Dye, R.A., 2001. An evaluation of "essays on disclosure" and the disclosure literature in accounting. J. Account. Econ. 32, $181-235$.

Dye, R.A., 2017. Optimal disclosure decisions when there are penalties for nondisclosure. RAND J. Econ. 48, 704-732.

Dye, R.A., Hughes, J.S., 2018. Equilibrium voluntary disclosures, asset pricing, and information transfers. J. Account. Econ. 66, $1-24$.

Einhorn, E., Ziv, A., 2008. Intertemporal dynamics of corporate voluntary disclosures. J. Account. Res. 46, 567-589.

Elshandidy, T., Fraser, I., Hussainey, K., 2015. What drives mandatory and voluntary risk reporting variations across Germany, UK and US?. Br. Account. Rev. 47, 376-394.

Elshandidy, T., Shrives, P.J., Bamber, M., Abraham, S., 2018. Risk reporting: A review of the literature and implications for future research. J. Account. Literature 40, 54-82.

Hail, L., Leuz, C., 2006. International differences in the cost of equity capital: Do legal institutions and securities regulation matter?. J. Account. Res. 44, 485531.

Heinle, M.S., Smith, K.C., 2017. A theory of risk disclosure. Rev. Acc. Stud. 22, 1459-1491.

Heinle, M.S., Smith, K.C., Verrecchia, R.E., 2018. Risk-factor disclosure and asset prices. Account. Rev. 93, 191-208.

Heritage Foundation (ed.), 2009. Index of Economic Freedom. The Heritage Foundation, Washington (DC).

Holthausen, R.W., 2003. Testing the relative power of accounting standards versus incentives and other institutional features to influence the outcome of financial reporting in an international setting. J. Account. Econ. 36, 271-283.

Jensen, M.C., Meckling, W.H., 1976. Theory of the firm. J. Financ. Econ. 3, 305-360.

Jorgensen, B.N., Kirschenheiter, M.T., 2003. Discretionary risk disclosures. Account. Rev. 78, 449-469.

Jorgensen, B.N., Kirschenheiter, M.T., 2007. Voluntary disclosure of sensitivity. Working paper.

Jorgensen, B.N., Kirschenheiter, M.T., 2012. Interactive discretionary disclosure. Contemporary Account. Res. 29, 382-397.

Jorgensen, B.N., Kirschenheiter, M.T., 2015. Discretionary disclosures to risk-averse traders: A research note. Contemporary Account. Res. 32, $1224-1235$.

Kaufmann, D., Kraay, A., Mastruzzi, M., 2009. Governance matters VIII: Aggregate and individual governance indicators, 1996-2008. Working Paper.

Kyle, A.S., 1985. Continuous auctions and insider trading. Econometrica 53, 1315-1335.

La Porta, R., Lopez de Silanes, F., Shleifer, A., 2008. The economic consequences of legal origins. J. Econ. Literature 46, $285-332$.

La Porta, R., Lopez-de-Silanes, F., Shleifer, A., Vishny, R.W., 1998. Law and finance. J. Political Economy 106, 1113-1155.

Leuz, C., 2010. Different approaches to corporate reporting regulation: How jurisdictions differ and why. Account. Business Res. 40, 229-256.

Leuz, C., Nanda, D., Wysocki, P.D., 2003. Earnings management and investor protection: An international comparison. J. Financ. Econ. 69, 505-527.

Levine, R., 1999. Law, finance and econonomic growth. J. Financial Intermediation 8, 8-35.

Li, S., 2010. Does mandatory adoption of International Financial Reporting Standards in the European Union reduce the cost of equity capital? Account. Rev. $85,607-636$.

Lin, Y., 2019. Soft and ambiguous risk disclosure. Working paper.

Lins, K.V., Servaes, H., Tamayo, A., 2011. Does fair value reporting affect risk management? International survey evidence. Financ. Manage. 40, 525-551.

Linsley, P.M., Shrives, P.J., 2000. Risk management and reporting risk in the UK. J. Risk 3, 115-129.

Smith, K., 2019. Risk disclosure, liquidity, and investment efficiency. Working paper.

Verrecchia, R.E., 1983. Discretionary disclosure. J. Account. Econ. 5, 179-194.

Verrecchia, R.E., 2001. Essays on disclosure. J. Account. Econ. 32, 97-180. 